\title{
Sanat Müzelerindeki Kopyalama Programlarının Tarihsel Temelleri ve Amerika'daki Uygulama Örnekleri
}

\section{Dr.Öğr.Üyesi Cihan Şule KÜLÜK ${ }^{1 *}$}

Geliş tarihi: 01.09.2019

Kabul tarihi: 19.09.2019

\section{Atıf bilgisi:}

IBAD Sosyal Bilimler Dergisi

Sayı: Özel Sayı Sayfa: $378-395$

Yıl: 2019

This article was checked by Turnitin. Similarity Index $4 \%$.

${ }^{1}$ Bolu Abant İzzet Baysal Üniversitesi, Türkiye, csule82@hotmail.com ORCID ID 0000-0002-8088-746X

\section{* Sorumlu yazar}

ÖZ

Görevini konservasyonun ötesine taşıyan ve çağdaş müzeciliğin gereğini uygulayan sanat müzeleri, sanatı üretenleri ve sanatı alımlayanları bir araya getirerek, sanatın farklı bağlamlarıyla anlaşılmasına dönük çalışmalar sunmaktadır. Bu çalışmaların başında, müzelerin sosyal hizmet çalışmaları kapsamında sunduğu, sanatçıların istek ve ihtiyaçları doğrultusunda hazırlanan "kopyalama programları" yer almaktadır. Sanatçıların ve sanat öğrencilerinin, sanat eserlerini incelemelerine, teknik olarak analiz etmelerine ve anlamalarına yönelik olarak sunulan bu program ile ayrıca sanatçların ve müze ziyaretçilerinin bir araya getirilmesi de hedeflenmektedir. Müzeler, kopyalama çalışmalarını "sanatçının hem görsel hem de teknik sözlügünü genişletip kendi eserini zenginleştirebileceği”" değerli bir yol olarak görmektedirler. $\mathrm{Bu}$ anlayış doğrultusunda kopyalama programları, müzelerin eğitim misyonunun da önemli bir parçasını oluşturmaktadır. Eski bir sanat formunun kopyalanmasını temsil eden bu geleneğin, dünyanın en önemli sanat müzelerinden biri olan Louvre'un halka açıldığı 1793 yılına dayandığı ve günümüzde de başta Amerika olmak üzere, Avustralya, Danimarka, Fransa, İspanya, Hollanda, İngiltere, İskoçya gibi gelişmiş ülkelerde de sürdürüldüğü görülmektedir. Türkiye'deki sanat müzelerinde ise kopyalama programlarına yer verilmediği görülmekte bu bağlamda bu araştırmanın, Türkiye'deki sanat müzeleri için örnek teşkil edeceği ve alan yazınına katkı sağlayacağı düşünülmektedir. Sanat müzelerindeki kopyalama programlarını tarihsel bağlamında ele alan ve Amerika'daki sanat müzelerinde günümüzde gerçekleştirilen kopyalama programlarını betimlemeyi amaçlayan bu çalışma, betimsel tarama modellinde olup, veriler doküman inceleme tekniğiyle toplanmıştır.

Anahtar Kelimeler: Sanat Müzeleri, Sosyal Hizmet Programları, Kopyalama Programları. 


\section{Historical Foundations of Copying Programs in Art Museums and Application Examples in the USA}

\section{Asst. Prof. Dr. Cihan Şule KÜLÜK ${ }^{1 *}$}

First received: 01.09 .2019

Accepted:18.09.2019

\section{Citation:}

IBAD Journal of Social Sciences

Issue: Special Issue Pages: $378-395$

Year: 2019

This article was checked by Turnitin. Similarity Index $4 \%$.

${ }^{1}$ Bolu Abant İzzet Baysal University, Turkey, csule82@hotmail.com

ORCID ID 0000-0002-8088-746X

*Corresponding Author

\begin{abstract}
Art museums, which carry the task beyond conservation and apply the necessity of contemporary museums, bring together art producers and art buyers and provide works to understand art in different contexts. Besides that, there are copy programs prepared by the museums in line with the wishes and needs of artists within the scope of social work activities. The program is designed to enable artists and art students to examine, technically analyze and understand artworks and aims to bring together artists and museum visitors. Museums see copying as a valuable way in which "the artist can expand both his visual and technical dictionary and enrich his own work". In line with this understanding, copying programs are an important part of the educational mission of museums. This tradition, which represents the replication of an old art form, dates back to 1793, when the Louvre, one of the world's most important art museums, went public, and now is also continued in developed countries such as Australia, Denmark, France, Spain, the Netherlands, England, and Scotland. It is seen that there is no room for coping program in the art museum in Turkey. In this context, it is thought that this study will be exemplary and will contribute to the literature for the art museums in Turkey. This study, which deals with the copying programs in art museums in historical context and aims to describe the copying programs performed in art museums in the USA today, is a descriptive scanning model and the data is collected by document analysis technique.
\end{abstract}

Key Words: Art Museums, Social Services Programs, Copyist Programs. 


\section{GİRIŞ}

"Başkalarını kopyalamak gereklidir, ancak kendini kopyalamak zavallılıktır."

Pablo Picasso

Gelişmiş ülkelerin kültür sanat politikaları doğrultusunda zengin sergiler ve etkinlik programları sunan sanat müzeleri, büyük kitlelere erişebilme yetkinlikleri ile toplumun görsel dünyalarını zenginleştirme, estetik duyarlık kazandırma gibi konularda belirleyici olmaktadır. Bu bağlamda sanat müzeleri, öğrenciler, engelliler, yaşlılar, çocuklar, göçmenler gibi çeşitli grupları temsil eden müze ziyaretçilerinin ve sanatçıların ilgi, istek ve ihtiyaçları doğrultusunda sosyal hizmet programları uygulamaktadır. Müzeler uyguladıkları bu farklı programlarla halkın tamamına ulaşmayı hedeflemektedir.

Sanat müzelerinin sosyal hizmet çalışmaları kapsamında sunduğu programlardan biri de sanatçıların istek ve ihtiyaçlarını göz önünde bulundurarak geliştirdikleri "kopyalama programlarıdır". Sanatçıların ve sanat ögrencilerinin, sanat eserlerini incelemelerine, teknik olarak analiz etmelerine ve anlamalarına yönelik olarak sunulan bu program ile ayrıca sanatçıların ve müze ziyaretçilerinin bir araya getirilmesi de hedeflenmektedir.

Casey Lesser, 2018 yılında kaleme aldığı makalesinde, sanat müzelerinin sunduğu "kopyalama programlarını", yetenekli sanatçıların, kamuya açık saatlerde, önemli sanat eserlerinin yanına şövalelerini kurarak kendi nefes kesici kopyalarını yapmalarına olanak sağlayan girişimler olarak tanımlamaktadır. Lesser, kopyalama programlarını değerlendirirken, Paris'teki Louvre Müzesinin, Madrid'deki Prado Ulusal Sanat Müzesi (Museo Nacional del Prado) ve Washington'da bulunan Ulusal Sanat Galerisi (National Gallery of Art) gibi dünyadaki belli başlı sanat müzelerindeki benzer programların mevcudiyetinin altını çizmektedir. Lesser'a göre; bu programlar, sanat tarihinin başyapıtlarından öğrenilmesine olağanüstü erişim sağlayarak, yaşayan ve çalışan sanatçıları desteklemektedir. S1kı kurallarla yönetilen bu saygın programlar, ziyaretçiler için müzeyi deneyimlemenin etkileyici bir yoluyken müzelerin eğitim misyonunun da önemli bir uzantısıdır.

Türk Dil Kurumu'nun Güzel Sanatlar Terimleri Sözlügünde (1968), "kopya”; "benzeti” olarak tanımlanırken Türk Dil Kurumu'nun Güncel Türkçe Sözlüğünde (2005), "kopya”: "bir sanat eserinin veya yazılı bir metnin taklidi”, asıl karşıtı olarak tanımlanmıştır. Sanat Kavramları ve Terimleri Sözlüğünde ise "kopya", "ünlü bir sanatçıya ait bir yapıtın bir başkasınca üretilen tıpkısı" olarak tanımlanmıştır (Sözen ve Tanyeli, 2009).

Tarih boyunca sanatçıların, başka sanatçıların eserlerini inceledikleri ve kullandıkları teknikleri öğrenmek adına, kopyadan yararlandıkları bilinmektedir. Ayrıca Pablo Picasso, Van Gogh, Francis Bacon, Edouard Manet gibi pek çok sanatçının, önceden yapılmış bir eserin yorumuna dayanan esinlenme/alıntı içeren yeniden üretimleri de mevcuttur. Kopya ve esinlenme/alıntı sanat dünyasında kabul görmüş birbirinden bağımsız kavramlardır ve ayrı işlevleri vardır. Sanat eserlerini kopyalama meselesi, sanatı anlamaya ve öğrenmeye dönük doğal bir çaba olarak görülürken esinlenme/alıntı ise yeniden üretimi doğuran bir ifade şekli olarak kabul görmüştür. Bu araştırmada, sanatçıların ve sanat öğrencilerinin bir sanat eserini incelemek, öğrenmek ve teknik deneyim kazanmak adına yapmış oldukları kopyalama çalışmaları ele alınmakta, bu bağlamda Amerika Birleşil Devletleri'ndeki sanat müzelerinde gerçekleştirilen kopyalama programlarına değinilmektedir. Kopyalama programı İngilizce alan yazınında "Copyist Program" olarak yer almakta ve bu çalışmada "kopyalama programı" şeklinde kullanılmaktadır. Eski bir sanat formunun kopyalanmasını temsil eden bu geleneğin, dünyanın en önemli sanat müzelerinden biri olan Louvre'un halka açıldığı 1793 yılına dayandığı ve günümüzde de başta Amerika olmak üzere, Avustralya, Danimarka, Fransa, İspanya, Hollanda, İngiltere, İskoçya gibi gelişmiş ülkelerde de sürdürüldüğü ancak Türkiye'deki sanat müzelerinde kopyalama programlarına yer verilmediği görülmektedir. $\mathrm{Bu}$ bağlamda yapılan araştırmanın, Türkiye'deki sanat müzeleri için örnek teşkil edeceği ve alan yazınına katkı sağlayacağı düşünülmektedir. $\mathrm{Bu}$ araştırmada, öncelikle kopyalama programları, tarihsel ve düşünsel temelleri bağlamında ele alınmış ve günümüzde kopyalama programlarını en etkin uygulayan sanat 
müzelerinden örnekler verilmiştir. Metropolitan Sanat Müzesi (Metropolitan Museum), Ulusal Sanat Galerisi (National Gallery of Art) ve Walters Sanat Müzesi'ndeki (The Walters Art Museum) kopyalama programlarının işleyişi betimlenmiştir. Sanat müzelerindeki kopyalama programlarını tarihsel bağlamında ele alan ve Amerika'daki sanat müzelerinde gerçekleştirilen kopyalama programlarını betimlemeyi amaçlayan bu çalışma, betimsel tarama modelli olup veriler doküman inceleme tekniğiyle toplanmıştır.

\section{Sanat Müzelerinde Uygulanan Kopyalama Programlarının Tarihsel ve Düşünsel Temelleri}

Günümüzde sanat müzelerinde uygulanan kopyalama programlarının en eski örneğinin, Louvre Müzesi'nde 1793 yılında Fransız Devrimi sırasında başladığını kaydeden Lesser (2018), o dönemde müzeye girmek isteyen ve ustaların çalışmalarını kopyalamak isteyen herhangi bir sanatçıya, şövale verilmesinin bir kural olduğunu belirtmektedir. Edgar Degas, Pablo Picasso ve Salvador Dalí gibi sanatçıların da Louvre Müzesi'nde kopya çalışmalar yaptığını ifade eden Lesser, günümüzde de bu geleneğin devam ettiğini ve her yıl 250 sanatçıya Louvre Müzesi'nde üç ay çalışması için yüksek imtiyazlı kopyalama izni verildiğini dile getirmektedir (Resim 1).

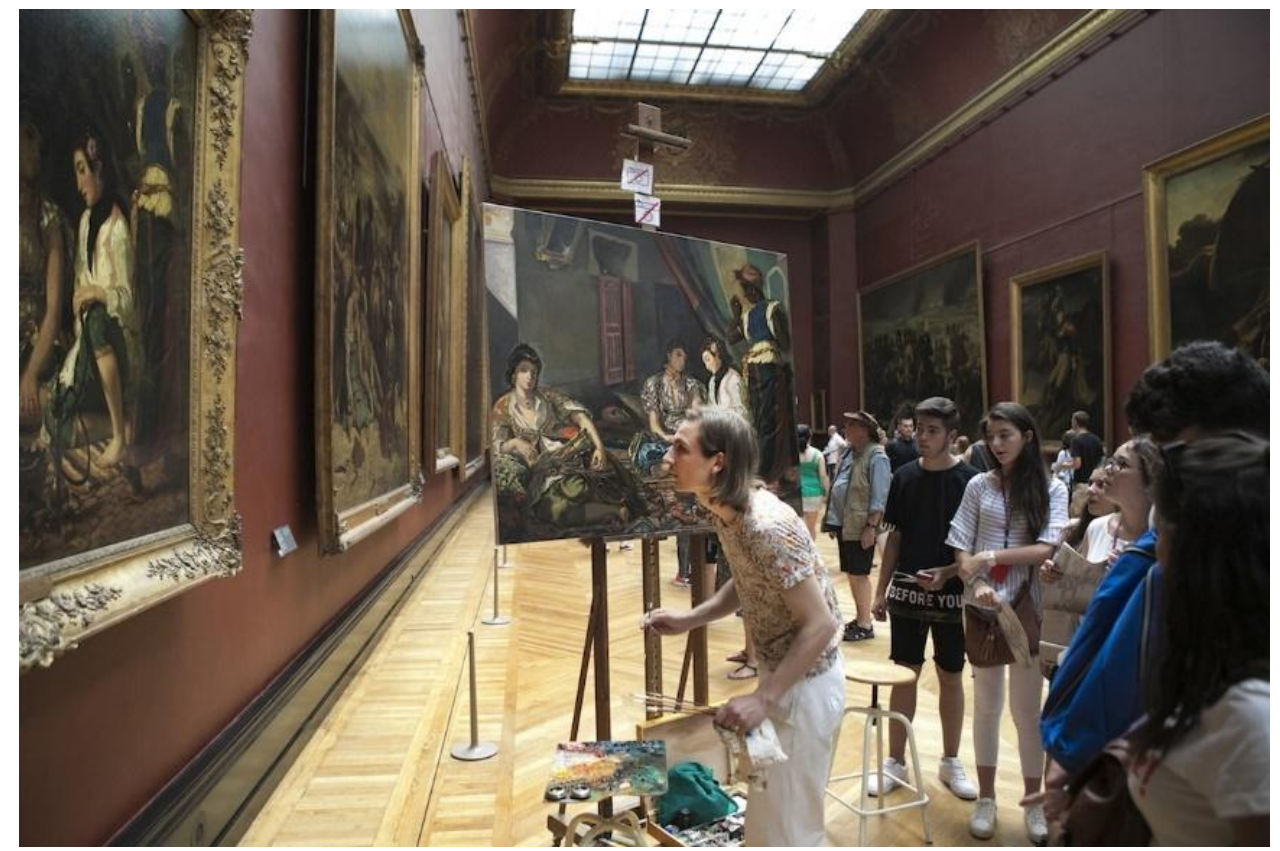

Resim: 1 “Louvre Müzesi’nde kopyalama yapan bir sanatçı ve müze ziyaretçileri”, 2017, Ivan Guilbert. [(http://www.ivanguilbert.com/les-copistes-du-louvre\#12), (Ert.15.05.2019)].

Louvre ilk kez 1793 yılında halka açıldığında, sanatçıların koleksiyonlarını incelemesi ve kopyalaması için on günde bir gün tekrarlanan özel bir program uygulanmaya başlanmıştı. Bu teşvik sayesinde Louvre'un büyük ölçüde Fransız sanatının laboratuvarı olarak tanınması sağlanmıştır. İlk Amerikan müzeleri neredeyse bir yüzyıl sonra kurulduğunda, Louvre'un politikasını benimsemişlerdi. Böylelikle sanatçılara ve öğrencilere galerilerindeki çalışmalardan resim kopyalama veya model alma izni vermek, müze eğitiminin temel aracı haline gelmişti (Newsom ve Silver, 1978).

Kopyalama çalışmalarının Avrupa sanat müzelerinde yeni yeni uygulanmaya başladığı dönemlerde, bu çalışmaların günümüze kıyasla olağanüstü bir çaba ile yürütüldüğü görülmektedir. Öyle ki Gutiérrez (2017), orijinal adıyla (Museo del Prado) Prado Sanat Müzesi'nin, 1819'da halka açıldığında, müze binasının haftanın bir günü temizlemeye kapatılarak ve sadece çarşamba günleri halka açılarak geri kalan haftanın beş gününün ise akademi öğrencilerinin ve sanatçıların kopya çalışmalar ve resim incelemeleri yapabilmeleri için tahsis edildiğini belirtmektedir (Resim 2). Kopyalama programları günümüzde de Prado Sanat Müzesi'nin misyonunun belirleyici bir hedefi olmakta ve gelecekteki sanatçılar için bir eğitim merkezi olmayı taahhüt etmektedir (Resim 3). 


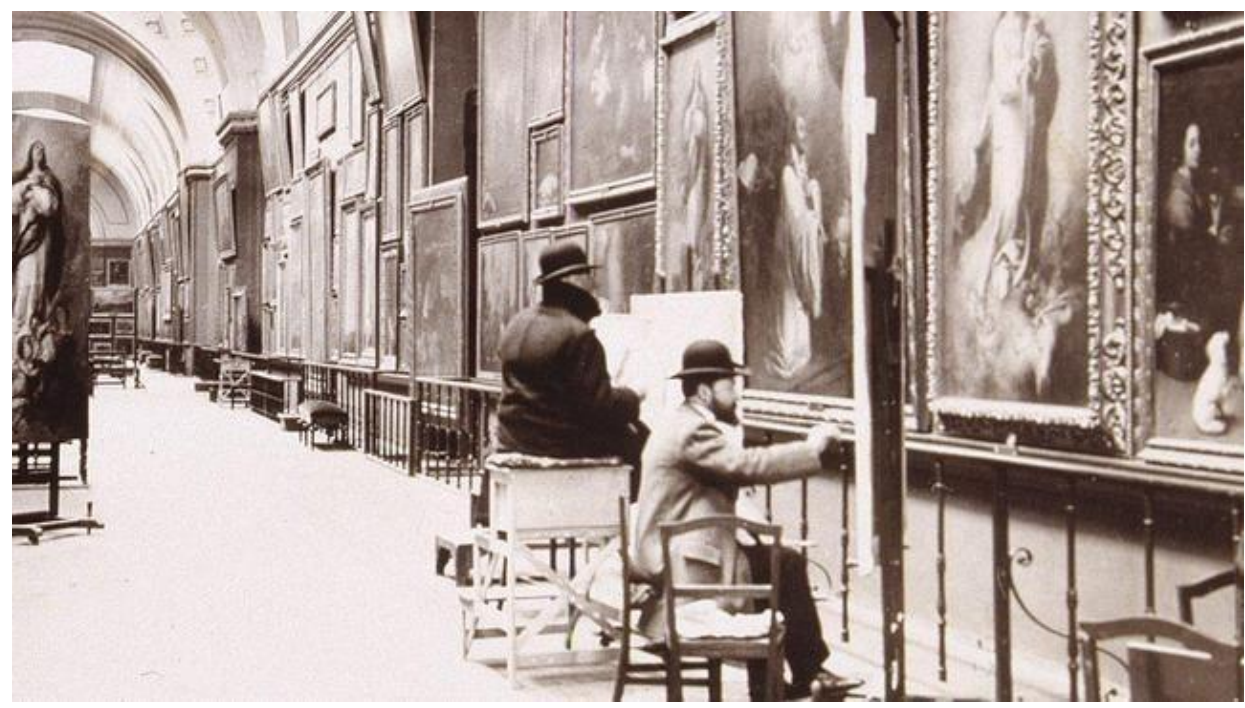

Resim: 2 “19. Yüzyıl'da Prado Sanat Müzesi’nde kopyalama yapan bir sanatçılar”, [(Gutiérrez, 2017 s.72.)].

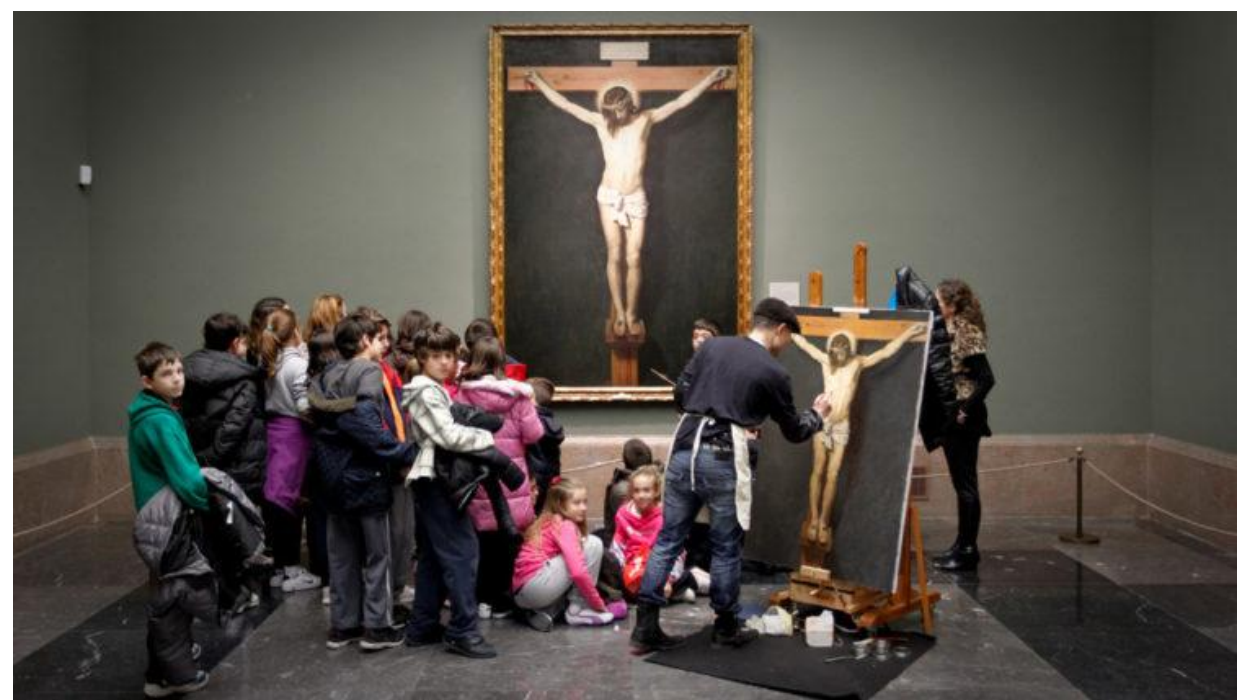

Resim: 3 "Prado Sanat Müzesi’nde kopyalama yapan bir sanatçı ve müze ziyaretçileri”, 2013. [(https://elpais.com/cultura/2013/01/27/album/1359245069_373345.html\#foto_gal_1), (Ert.15.05.2019)].

Avrupa'da orijinal sanat eserleri öyle büyük bir tutkuyla kopyalanıyordu ki sonunda kopya eserlerin toplanacağ 1 ve sergileneceği bir kopya eserler müzesi açıldı. Kopyalama çalışmalarına neden bu kadar önem verildiğini Jacobs (2019), tarihsel bağlamında ele alır ve şöyle açıklar;

"Musée des Copies (Kopyalar Müzesi) 1872'de kuruldu ve ertesi yıl halka açıldı. Fransız hükümeti güzel sanatlar direktörü Charles Blanc'ın projeyi şahsen desteklediği tanınmış ve de az tanınmış sanatçılar tarafından yapılmış kopyalardan oluşan Avrupa'daki en iyi 150 resimin yer aldığı koleksiyon ziyarete açıldı. O zamanlar kopyalarla dolu bir müze bugün olduğundan daha az garip görünüyordu. Ünlü tabloların çoğaltılmasının 19. yüzyılda Fransa'da önemli bir yeri vardı. Louvre'da kopyalamak için belirlenmiş günler vardı ve müze salonları kadın ve erkek ressamların kopyalama çalışmalarına ev sahipliği yapıyordu. Öğrencilerin, eski ustaların tarzına hâkim olmaları ve çalışmalarını kopyalayarak öğrenmeleri bekleniyordu. Ayrıca o dönemde hiç kimsenin danışabileceği yüksek çözünürlüklü fotoğraflar da yoktu. Saygın ressamlar da sürekli bir eğitim yöntemi olarak kopya çalışmalar yapmaya devam ettiler. İzlenimci hareketi kurmaya devam edecek ressamların bazıları bu geleneksel yoldan eğitim almışlardı. Édouard Manet 1850'lerin sonunda Louvre'da Rubens'in bir eserini kopyalamıştı. Çok iyi kopyalama yapabilmek değerli bir beceriydi. Bazı sanatçılar yaşamlarını sürdürmek için, özel sektör ve devlet kurumlarına özellikle elçiliklere ve kamu binalarına asılacak kopyalar üretti. Ancak sanat eğitimi alanındaki anlayış değişikliği ve ardından gelen eleştiriler 
1873 y1lında iki yıldan daha kısa bir süre sonra Kopyalar Müzesi’nin kısa ömrünü sonlandırdı. Çok renkli gravürler ve gittikçe daha ileri düzeyde ve erişilebilir fotoğrafçılık, Fransa sanat dünyasında kopyanın öneminin azalmasına katkıda bulundu. Blanc'in gelecek nesillere zamansız bir anıt olmasını beklediği müze, Paris'in uzun sanatsal tarihinde meraklı bir dipnottan öteye gidemedi”.

Modernizmin ilkeleri, 1930'larda profesyonel sanat eğitimine dâhil edilmeye başladığında, kopyalama yöntemi temel bir öğrenme aracı olarak temelini kaybetti. Van Gogh, Delacroix, Cezanne, Poussin, Matisse, De Heem, Derain ve Breughel gibi modern ustaların yaptığı önemli kopyaları, bireysel ifadeler ve yeni estetik ilkeler peşinde koşan sanatçılar tarafından unutuldu. 1970'lere gelindiğinde, sanatçıları binlerce yıldır yönlendiren bir süreç neredeyse sona ermişti. Her ne kadar Avrupa, sanat eğitimi bu geleneği sürdürmüş olsa da kopyalama programlarının hala sürdürüldüğü birkaç Amerikan müzesinde, çoğunlukla yaşlı ve amatör ressamlar için çağın gerçeğini yakalayamayan bir boş zaman etkinliğine ve bir eğlenceye dönüşmüştü (Newsom ve Silver, 1978).

Erin Blakemore 2016 yılında Smithsonian Dergisi'nde ele aldığı makalesinde; günümüzde, sanatçıların başka sanatçıların eserlerini kopyalamasının, şaşırtıcı görünebilir olsa da aslında bin yıldır görsel sanatların hayati bir parçası olduğunu ifade etmektedir. Blakemore'a göre; büyük ustalar rutin olarak bu sürece katılarak, kendi sanat imzalarını/mühürlerini kendilerinden önce gelen sanatçılardan kazandılar. Örneğin; Paul Cézanne, Eugène Delacroix'in çalışmalarını takıntı haline getirmişti, çalışmalarını, kendi ilhan perilerine yakışır bir hürmet gösterme çabasıyla tekrar tekrar kopyalamıştır. Vincent van Gogh da pek çok sanat eserinin kopya çalışmasını yapmıştır ve Caravaggio'nun çalışmalarının kopyalarını yapan ressamlar, zaman içinde kaybedilen tabloların korunmasına yardımcı olmuştur.

Günümüzde, Metropolitan Sanat Müzesi'ndeki Louvre'daki, Ulusal Sanat Galerisi'ndeki, diğer kurumlardaki kopyalama programları ve benzer programlar, birbirleriyle rekabet etmekte ve halk tarafından çok sevilmektedir. Ancak müzelerde kopyalama programlarına katılan sanatçılar her zaman sayg1 görmemiştir. Örneğin; 1887'de The New York Times, Louvre'daki kopyalama programlarına katılan sanatçıları alay konusu yapan bir makale yayınlamıştır. Neyse ki, kopya çalışmaları yapan sanatçılara yönelik bu görüş daha sonra ortadan kaybolmuştur. Sonuçta, taklit etme /kopyalama hem bir övme hem de bir öğrenme şeklidir ve sanat eleştirmenlerinden müze başkanlarına kadar herkes bu uygulamayı sıcak bir şekilde karşılamaktadır. (Blakemore, 2006). Amerika'daki kopyalama çalışmalarının sanat müzelerinde uygulanması ve ülke geneline yayılması konusundaki çalışmalar, Metropolitan Sanat Müzesi'nde 1900'lü yıllarda çekilmiş fotoğraflarla da belgelenmektedir (Resim 4), (Resim 5). 1887'de Avrupa'daki sanat müzelerinde gerçekleştirilen kopyalama çalışmalarına en ağır eleştirileri getiren Amerika'nın, günümüzdeki kopyalama programlarının en iyi uygulayıcısı olması ise dikkat çekici bir durumdur.

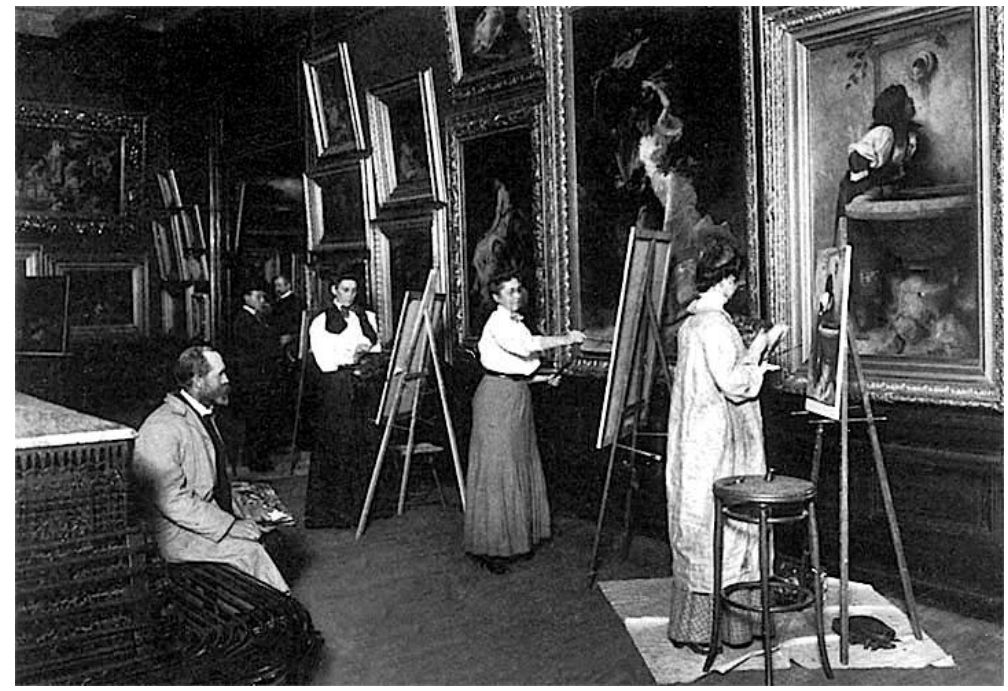

Resim: 4 "Metropolitan Sanat Müzesi'nde kopyalama yapan sanatçılar", 1900. [(https://www.pbase.com/johnglines/image/149678582), (Ert.15.05.2019)]. 


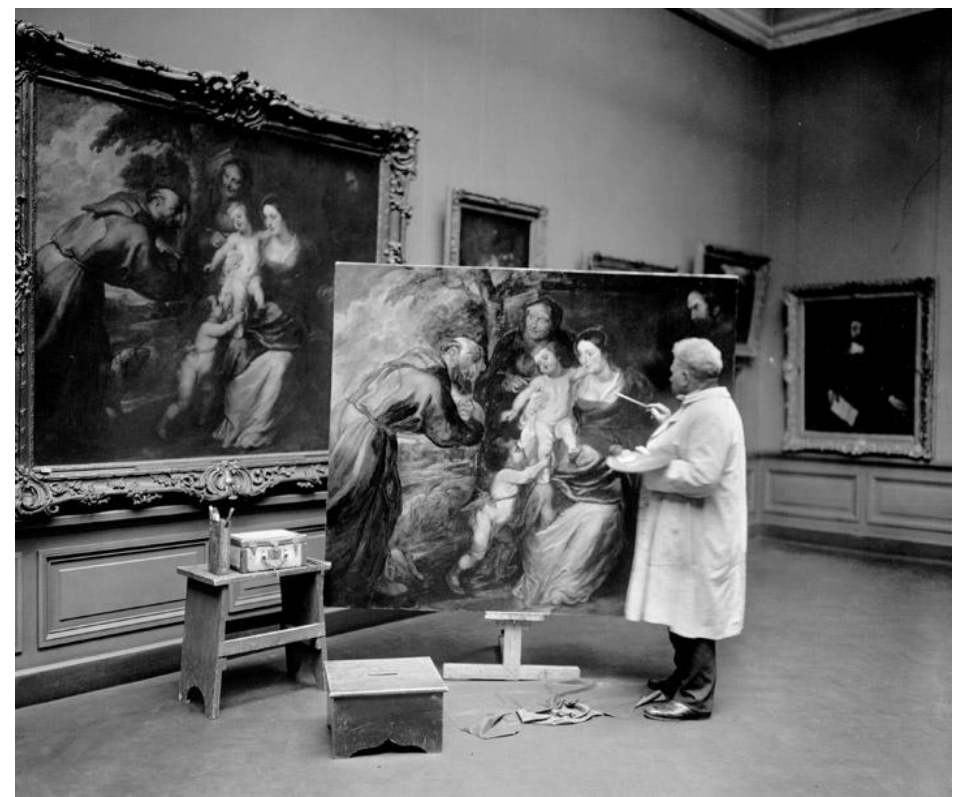

Resim: 5 "Metropolitan Sanat Müzesi'nde kopyalama yapan bir sanatçı”, 1902-29.

[(https://www.metmuseum.org/blogs/now-at-the-met/2016/the-met-copyist-program), (Ert.15.05.2019)].

Tarih boyunca kopyalama işinin hem sanat öğrencileri hem de başarılı sanatçılar için eğitsel bir uygulama olarak kullanıldığını belirten Blakemore' (2006) kopyalama çalışmalarının başka olumlu taraflarının da olduğunu ifade etmektedir. Blakemore, Caravaggio'nun eserlerinin birçoğunun yok olmasına rağmen, halen var olan önemli sayıda kopya sayesinde, eserlerinin eksiksiz bilgisine sahip olunduğunu vurgulamaktadır. Blakemore bunlara ek olarak; Metropolitan Sanat Müzesi koleksiyonun, Van Gogh'un, Millet'in orijinal eserlerinin "çevirileri" olarak nitelendirdiği ve "First Steps" isimli eseri de dahil olmak üzere bir dizi kopya çalışmayı kapsayan pek çok eseri de içerdiğini belirtmektedir.

Sanat müzelerinde yapılan kopyalama geleneğini tasvir eden pek çok önemli sanat eserinin de varlığından söz etmek gerekirse, New York kentindeki Brooklyn Sanat Müzesi’nde bulunan Winslow Homer tarafindan ahşap kazıma tekniğinde 1868 yılında yapılan orijinal adıyla "Art-Students and Copyists in the Louvre Gallery, Paris" isimli eseri örnek verebiliriz (Resim 6). Louvre Müzesinin galerilerinde kopyalama çalışmaları yapan sanatçı ve öğrencileri betimleyen Homer, bu çalışmada Fransa İç Savaşı sonrası kadınlar için sanat eğitimindeki devrimi ele almıştır (Brooklyn Museum, 2019).

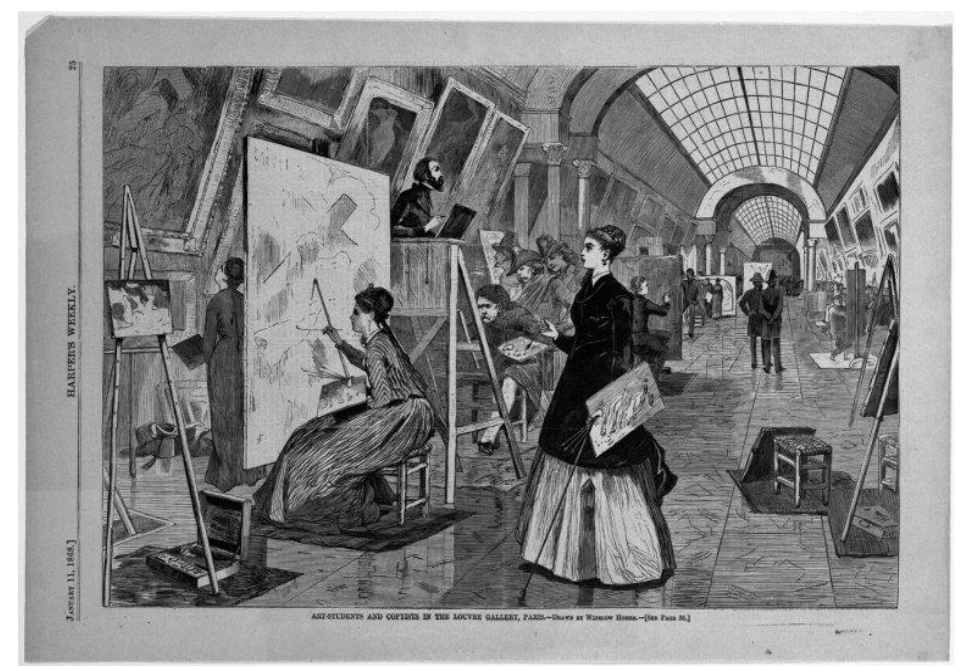

Resim: 6 Winslow Homer, “Art-Students and Copyists in the Louvre Gallery, Paris”, 1868. [(https://archive.org/details/brooklynmuseum-o2482-art-students-and-copyists), (Ert.15.05.2019)]. 
Clark Sanat Müzesi koleksiyonunda bulunan orijinal adıyla "Amerıcans Abroad- the Copyist in the Louvre" olarak bilinen eser, Charles Stanley Reinhart tarafından yapılmıştır (Resim 7). 1890 yılında, ağaç baskı tekniğiyle yapılan eser, Louvre müzesinde kopya çalışma yapan kadın bir sanatçıyı ve onu izleyen müze ziyaretçilerini konu almaktadır (Clark Museum, 2019). Müzelerdeki kopyalama çalışmalarını konu alan ve farklı dönemlerde yapılmış bu eserler, konuyu tarihsel ve düşünsel temelleri bağlamında değerlendirirken önemli bir belge niteliği taşıması açısından önemlidir.

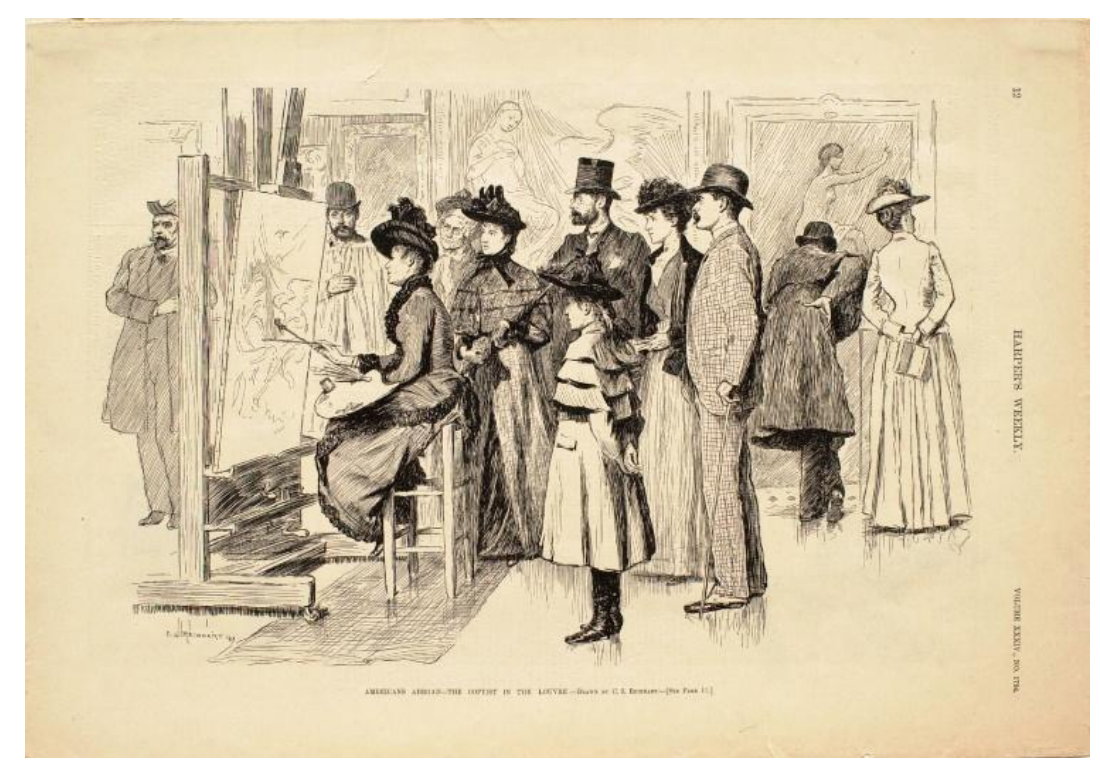

Resim: 7 Charles Stanley Reinhart, “Amerıcans Abroad- the Copyist in the Louvre”, 1890.

[(https://www.clarkart.edu/Collection/6382), (Ert.15.05.2019)].

On dokuzuncu yüzyılda aynı konuyu temel alan bir eser de 1897 yılında Isidre Nonell tarafindan mürekkep ve karakalem tekniğiyle yapılmış bir çizimdir (Resim 8). Orijinal adı "Copista en el Museu del Louvre" olan eser İspanya’nın Barselona kentinde bulunan Katalan Ulusal Sanat Müzesi arşivinde yer almaktadır. Bu eserde Louvre Müzesinde kopyalama yapan bir erkek sanatçı ve kadın bir müze ziyaretçisi resmedilmiştir (Museu Nacional d'Art de Catalunya, 2019).

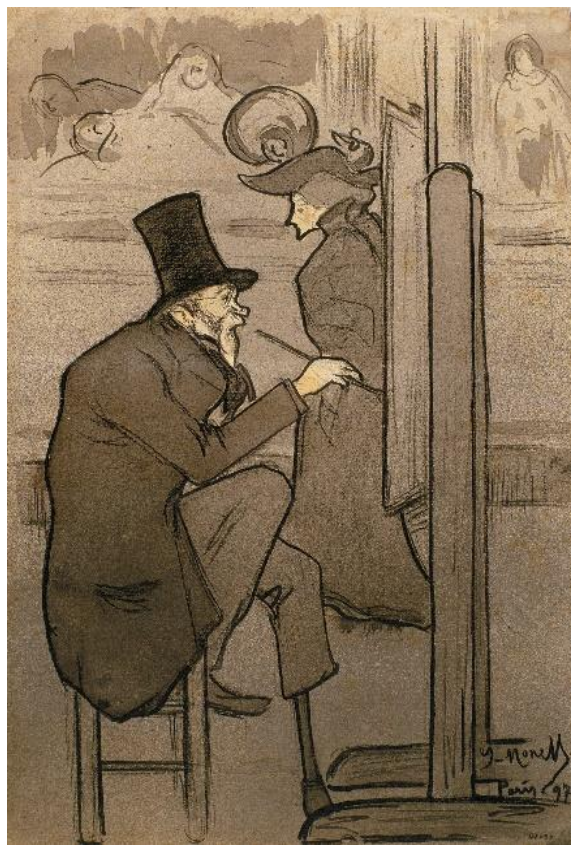

Resim: 8 Isidre Nonell, “Copista en el Museu del Louvre”, 1897.

[(https://www.museunacional.cat/en/file/041090-djpg), (Ert.15.05.2019)]. 
Sanat müzelerindeki kopyalama geleneğini tasvir eden bir başka sanatçı da John Sloan'dır. Sanatçının 1908 tarihli gravür tekniğiyle yaptığı eser, Smithsonian Amerikan Sanat Müzesi'nde bulunmaktadır. Orijinal adiyla "Copyist at the Metropolitan Museum (An Amateur Artist)" isimli eserinde Metropolitan Sanat Müzesi'nde kopyalama çalışması yapan bir amatör sanatçıyı tasvir etmiştir (Resim 9), (Smithsonian American Art Museum, 2019). Gravür bask1 tekniğyle yapılmış bu eserin diğer baskıları da High Sanat Müzesi (High Museum), Ulusal Portre Galerisi (National Portrait Gallery) gibi Amerika Birleşik Devletleri'ndeki sanat müzelerinin arşivlerinde bulunmaktadır.

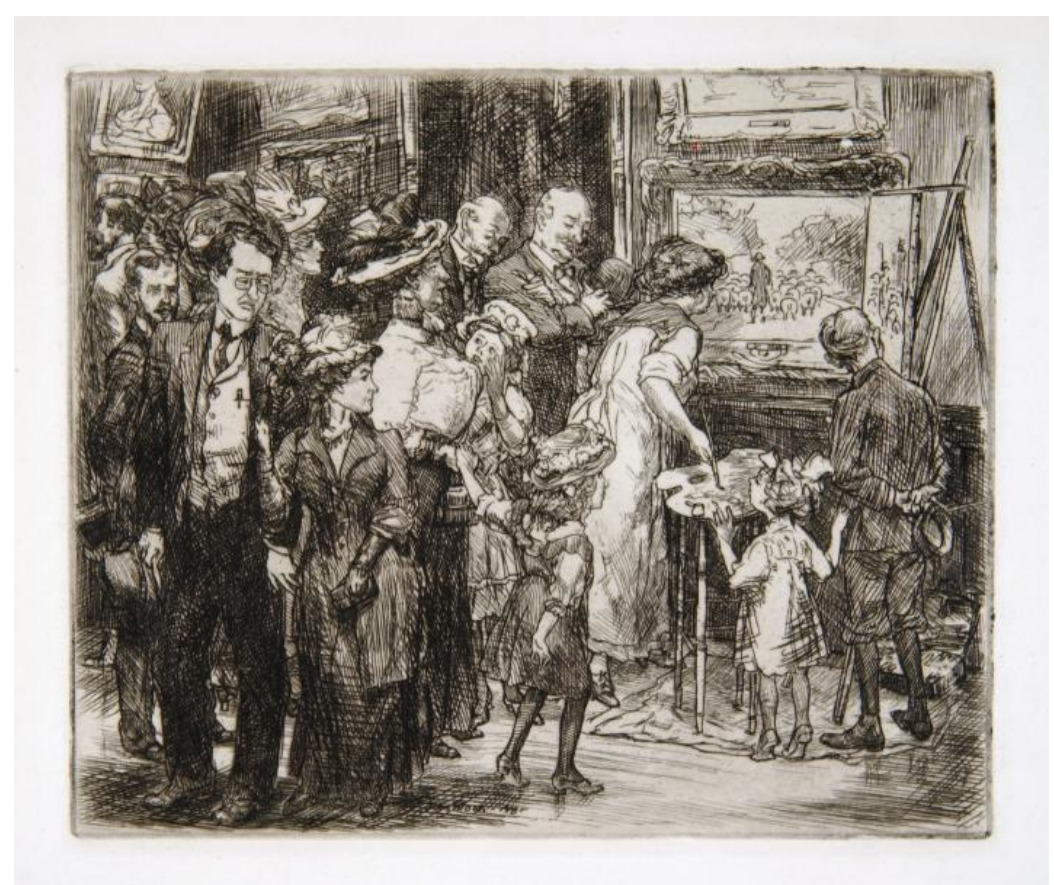

Resim: 9 John Sloan, "Copyist at the Metropolitan Museum (An Amateur Artist)", 1908.

[(https://americanart.si.edu/artwork/copyist-metropolitan-museum-amateur-artist-22490), (Ert.15.05.2019)].

Julius Bloch tarafindan, 1930 yılında yapılan ve orijinal adı "The Copyist 1930" olan eser, müzede kopyalama yapan sanatçılarının tasvir edildiği başka bir örnektir (Resim 10). Whitney Amerikan Sanatı Müzesi arşivinde bulunan ve litografi baskı tekniğiyle yapılmış eserde, yine müzede kopya çalışma yapan bir ressam ve onu izleyen müze ziyaretçileri resmedilmiştir (Whitney Museum of American Art, 2019).

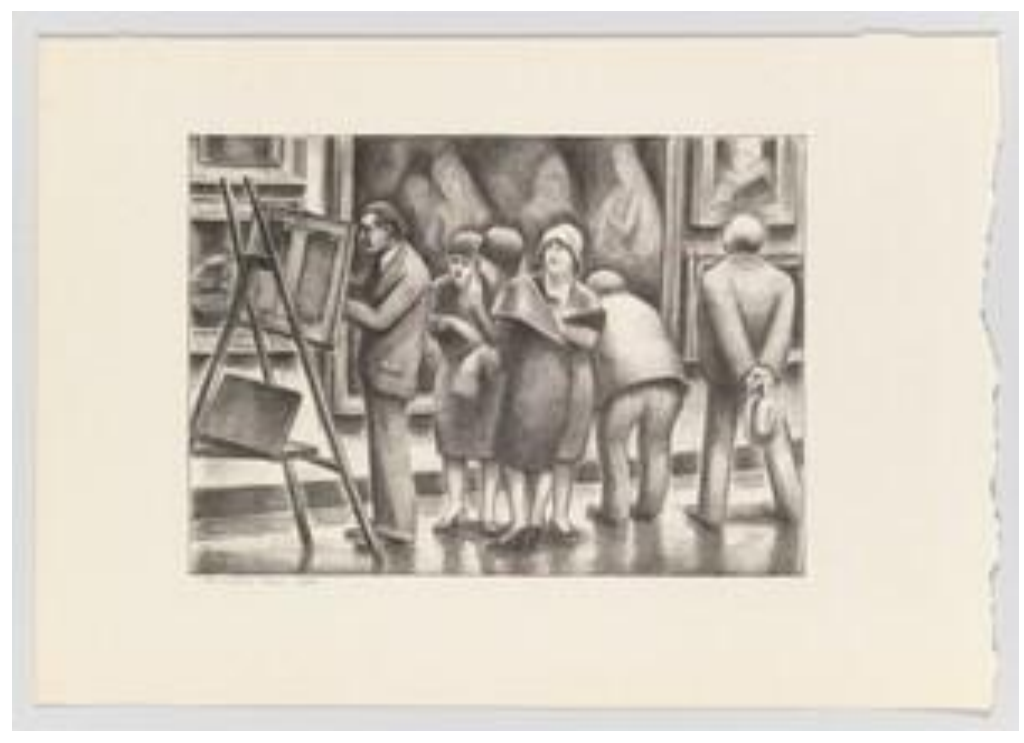

Resim: 10 Julius Bloch, “The Copyist 1930”, 1930.

[(https://whitney.org/collection/works/10228), (Ert.15.05.2019)]. 
Günümüzde dünyanın farklı yerlerinde bulunan önemli sanat müzelerinde, orijinal sanat eserlerinin kopyalanmasını ya da bu eserlerden yola çıkarak/esinlenerek yeni sanat eserlerinin üretilmesini destekleyen çalışmalar da yapılmaktadır. Örneğin; sanatın yeniden üretiminin eskiden beri sanatın bir parçası olduğunu ve eski ustaların eserlerin kopyalama işinin, genç sanatçıların kendi tarzlarını geliştirmeleri için mükemmel bir yol olduğuna inanan Hollanda Ulusal Sanat Müzesi, şaheserlerini kopyalayan sanatçıları ve tasarımcıları ödüllendirmektedir. Müze, New York kentindeki Modern Sanat Müzesi'nde bulunan Rijks Müzesi sanat koleksiyonunu temel alan ve bu koleksiyondan esinlenerek yeni eserler yaratan sanatçı ve tasarımcılara nakit ödüller veren üç yıllık bir program başlatmıştır (Quito, 2016).

Müzelerin sunduğu kopyalama programlarına dâhil olan katılımcılar artık sadece resim kopyalamakla da sınırlı değildir. Lesser'a göre (2018), kopyalama programı çok uzun zamandır devam eden bir gelenek olduğu için kopyalama konusunda müzeler, her zaman açık fikirli bir duruş sergilemekte ve son birkaç yıldır insanların dijital işleri yorumlamasına da olanak sağlamaktadır. Metropolitan Sanat Müzesi, sanatçıları, eserin sanal gerçeklik kopyasını oluşturmak için dijital resim teknolojisini kullanması ya da galeride dokuma tezgâhı kurarak Orta Çağ halılarını kopyalaması gibi boya dışındaki ortamları kullanmaya teşvik etmektedir. Müze ayrıca, sanatçıların heykel kopyalar yapabilmelerine de olanak sağlamaktadır.

Ancak sanat müzelerinde gerçekleştirilen kopyalama çalışmaları ile ilgili riskler de vardır. Örneğin; resim yaparken kullanılan boya sanat eserlerine ya da müzenin zemine sıçrayabilir, cılız şövaleler sanat eserlerinin üzerine düşebilir ayrıca bu çalışmalar sırasında diğer ziyaretçilerin görüşleri engellenebilir. $\mathrm{Bu}$ gibi riskler nedeniyle müzeler kopyalama programlarının yürütülmesi için gerekli şartlar ve yönergeler belirler. Sanatçıya verilen her izinle birlikte uzun kurallar ve düzenlemeler listesi açıklanır. Tek evrensel kural ise; sanatçıların kopyalayacakları orijinal sanat eseri ile aynı boyutta tuval kullanamayacak olmalarıdır çünkü bu durum, sahteciliğe zemin oluşturur. Müze de kopyalama çalışmalarının sorunsuz bir şekilde yürütülebilmesi için alınan kurallar ve belirlenen yönergeler, değişkenlik gösterse de genelinde sanat eserinden belli bir mesafede uzaklıkta çalışmak, onaylanmış şövale kullanmak, yalnızca müze trafiğinin yoğun olmadığı belli saatlerde çalışmak ve çalışma yaparken ziyaretçilerin görüş açılarını engellemeyecek biçimde pozisyon belirlemek gibi ortak hükümleri içerir. Müzede gerçekleștirilen kopyalama çalıșmaları müzenin güvenlik görevlisinin kontrolünde gerçekleştirilir. Kopyalama programına dahil olan sanatçıların yalnızca bir eser üzerinde çalışmasına izin verilir. Kopyalanacak orijinal eserin önceden belirlemesi ve müzeye bildirilmesi gerekir. Müzeler sadece sahip oldukları eserlerin telif haklarını kontrol ederler, bu nedenle kopyalama programları müzelerin kendi kalıcı koleksiyonlarındaki eserleri kapsar geçici sergilerdeki eserlerin kopyası yapılamaz (Graves, 2008).

Susan Cohen 2016 yılında sanat müzelerinde kopyalama programlarını en etkin kullan sanatçılardan biri olan Maya Valladares ile röportaj gerçekleştirmiştir. Kopyalama programlarının zengin tarihini, sanatçılara sunduğu olanakları ve dünya standartlarında bir müzenin eserlerini çoğaltmanın nasıl bir deneyim olduğunu anlatan Valladares, müzelerin bu programları, kamuya hizmet etmenin önemli bir yolu olarak gördüğünü vurgulamaktadır. Valladares'a (2016) göre, kopyalama programları, insanların orijinal sanat eserlerinden öğrenmelerini ve araştırmalarını sağlar. 1872'deki motivasyon da bu yöndeydi ve günümüzde de aynı doğrultuda devam etmektedir. Kopyalama programları, galerideki orijinal sanat eserini yaratan insan, bu eseri kopyalayan insan ve bu galeriyi ziyaret eden insan arasında önemli bir köprüdür. Amerika Birleşik Devletleri'ndeki sanat müzelerinde uygulanan kopyalama programlarında yalnızca resim değil heykel ve tekstil alanında da çalışmalar yapılmakta ve müzeler bu programları belli kurallarla yönetmektedir. Örneğin; sanatçı eserini müzenin belirlediği zaman diliminde tamamlamak ve kopyalayacağı eseri önceden müzeye bildirmek durumundadır. Müzeler, sanatçılara galerilerdeki tüm eserler için erişim izni vermek istese de lojistik unsurları da dikkate almak durumunda ve belirli kurallar koymak zorundadır. Müze ziyaretçilerinin ve sanatçıların eserlere erişimi konusunda da her zaman bir dengeyi gözetmek ve müzedeki ziyaretçi akışını bozmayacak önlemleri almak durumundadır. Bu nedenle, bir odada üç sanatçı birden kopyalama çalışması yapamaz. Kopyalanacak bir resmin veya heykelin ya da herhangi bir eserin bir kapiya çok yakın olup olmadığı, bir geçiş yoluna yakın olup olmadığı, köşede bulunup bulunmadığı gibi 
kopyalama sırasında görüşün engelleneceğini durumlar müze tarafından göz önünde bulundurulmaktadır.

Graves'e göre (2008), her sanat müzesinin bir kopyalama programı yürütmesi oldukça zordur. Çünkü bu programların hayata geçirilebilmesi yoğun emek gerektirir ve müzelerin çoğunun bunu gerçekleştirecek kaynağı yoktur. Bazı Avrupa müzelerinin ve daha küçük ölçekli Amerika müzelerinin kopyalama programı uygulamaya istekli olsalar da müze mekanlarının bu işe elverişli olmaması ve uygun fiziksel ortamın sağlanamaması nedeniyle programları gerçekleştirememektedirler. Avrupa geleneğine bağlı olmayan daha genç müzeler ise kopyalama programlarını sıkıcı ve modası geçmiş olarak görebilirler. Ancak unutulmamalıdır ki galeride çalışan bir sanatçı, müzenin bir mezarlık değil, dağınık yaşam döngüsünün bir parçası olduğunu gösteren derin bir semboldür.

Bunların ötesinde, dünyaca ünlü sanat müzelerinde bir eseri kopyalayabilmek için neler yapılması ve hangi şartların sağlanması gerektiğine ilişkin soru işaretleri vardır. Örneğin; herkes müze de kopyalama programlarına katılabilir mi? İstenilen her eser kopyalanabilir mi? Kopyalama çalışmalarında herhangi bir kısıtlama var mı? Kopyalama programlarına katılabilmek için müzeye herhangi bir ücret ödeniyor mu? kopyalama yapan sanatçılar için müzenin sağladığı bir fon var mı? Gerekli malzemeleri kim temin ediyor? Kopyalanan eser ne kadar sürede tamamlanmalı? gibi sorulara, müzelerin kopyalama programlarını en iyi şekilde yürütebilmek için hazırladığı yönergelerin incelenmesi ile yanıt aranacaktır.

\section{Metropolitan Sanat Müzesi (Metropolitan Museum)}

Dünyanın en önemli sanat müzelerinden biri olarak kabul edilen Metropolitan Sanat Müzesi Amerika Birleşik Devletleri'nin New York kentinde bulunmaktadır. 1872'de kapılarını ziyaretçilere açtığı ilk günden bu yana iki milyondan fazla eser içeren koleksiyonuyla şehrin en çok ziyaretçi çeken sanat merkezlerinden biridir. Müze, sosyal hizmet politikası gereğince pek çok program uygulamaktadır. Bunlardan birisi de sanatçıların ilgi ve ihtiyaçları doğrultusunda geliştirilmiş ve önemli bir geleneğin temsili olan kopyalama programlarıdır (Metropolitan Museum, 2019).

Metropolitan Sanat Müzesi, sanatçı programları kapsamında sunduğu "kopyalama programı" ile sanatçılara bir sanat eserini kopyalamaları ve tekniklerini geliştirmeleri için zaman ve mekân sunmaktadır. Metropolitan Sanat Müzesi bu program ile 1872'den bu yana müzenin koleksiyonundaki orijinal eserlerin yeniden yorumlanmasını sağlamaktadır. Program, yoğun teknik çalışmayı ve derin gözlemi desteklerken resim, heykel ve tekstilin dâhil olduğu ancak bunlarla da sınırlı olmayan pek çok alanı kapsayan çeşitli ortamlar sunarak sürekli katılımını teşvik etmektedir (Resim 11), (Resim 12), (Metropolitan Museum, 2019b).

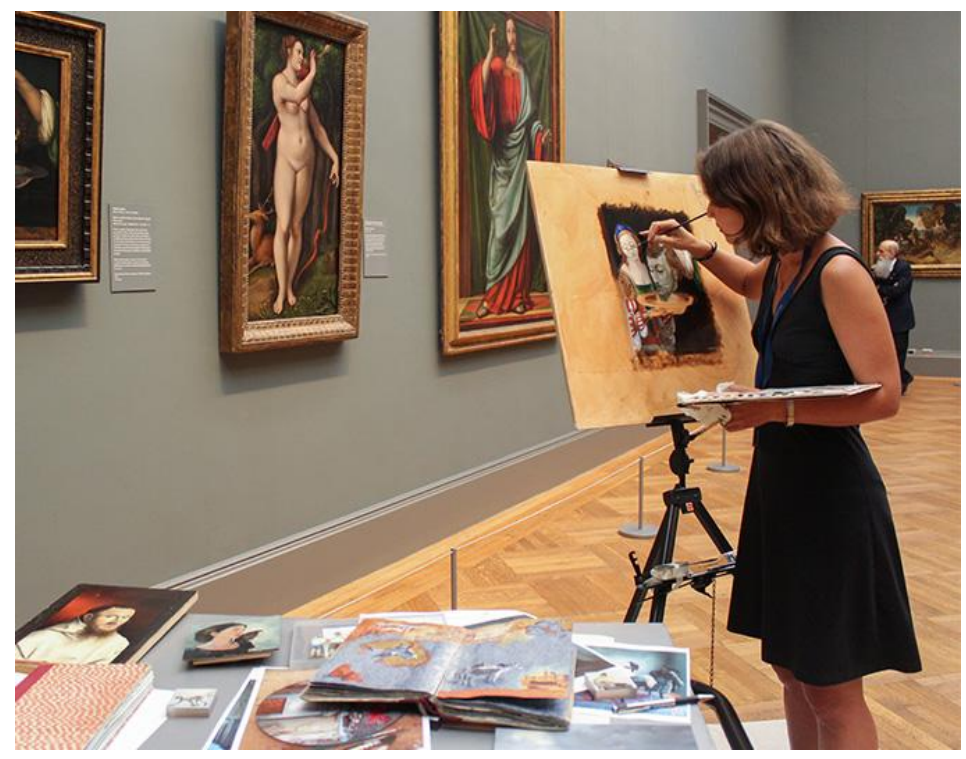

Resim: 11 "Metropolitan Sanat Müzesi’nde resim kopyalayan bir sanatçı".

[(https://www.metmuseum.org/events/programs/met-creates/copyist-program) (Ert.15.05.2019)]. 


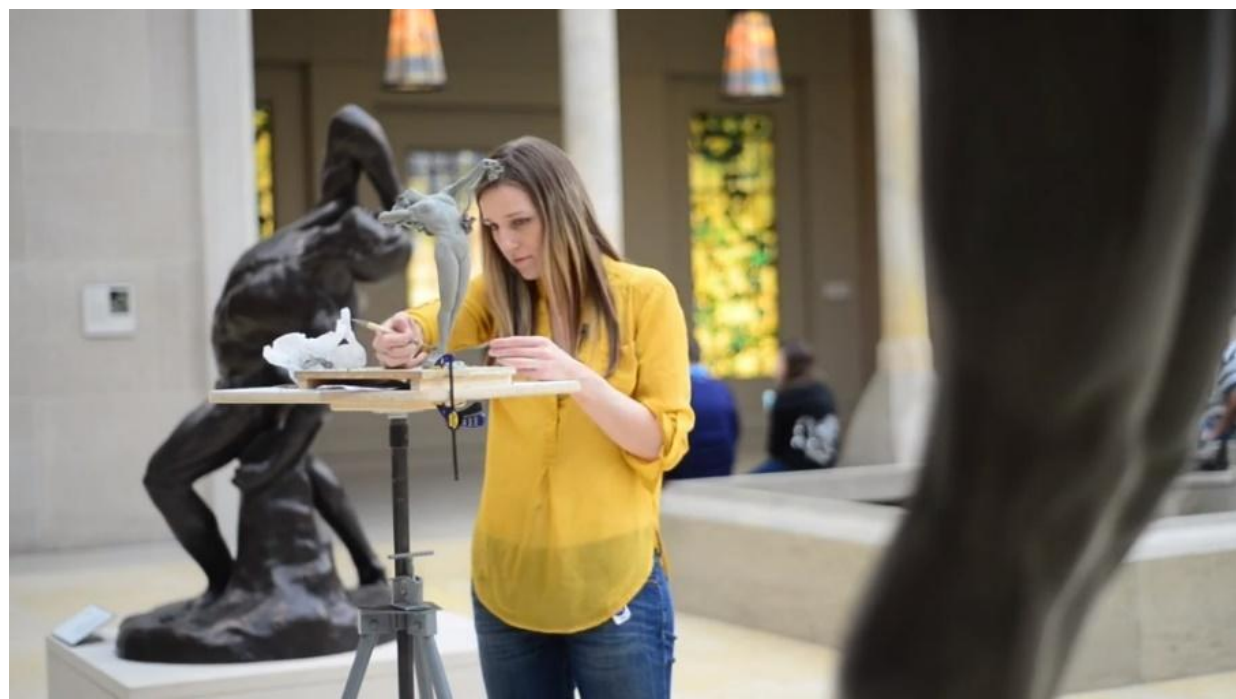

Resim: 12 "Metropolitan Sanat Müzesi'nde heykel kopyalayan bir sanatçı".

[(https://www.metmuseum.org/metmedia/video/metkids/metkids-qanda/sebastian-interviews-a-copyist), (Ert.15.05.2019)].

Metropolitan Sanat Müzesinin kopyalama programlarında çalışan bir sanatçı aynı zamanda müzenin bolog yazarı olan Murphy, (2016) makalesinde: Metropolitan Sanat Müzesi kopyalama programının, müzenin aç1lışından iki yıl sonra 1872 'de başlayan ve müzede sürdürülen en uzun program olduğunu belirtmektedir. O zamandan beri, sayısız sanatçının ve sanat öğrencisinin bu programa katıldığını ve pek çok farklı deneyim kazandığını ifade eden Murphy, bu programın olumlu tarafları olduğu gibi olumsuz taraflarının da olduğunu vurgulamaktadır. Murphy, çalışma alanının çevresinde toplanan dikkat dağıtıcı büyük kalabalıklar, kendi kontrollerinde olmayan kesintiler ya da sınırlı sürede çalışmayı tamamlama zorunluluğu gibi kısıtlamalar olsa da sanatçının sanat pratiklerinde edindiği deneyimi ile her yaştan ve etnik kökenden gelen müze ziyaretçisiyle kurduğu doğrudan iletişimi paha biçilmez olarak nitelendirmektedir.

Günümüzde hala devam eden Metropolitan Sanat Müzesi kopyalama programının sorunsuz bir şekilde ilerlemesi, müzedeki ziyaretçi akışının engellenmemesi ve galerilerdeki orijinal sanat eserlerinin zarar görmemesi adına programa dâhil olacak katılımcılar için belirli koşullar ve yönergelerin uygulandığı görülmektedir. Programa katılmak isteyen profesyonel sanatçıların, sanat öğrencilerinin ya da kursiyerlerin, müzenin belirlediği bu koşullara ve yönergelere uyması bu kapsamda bir sözleşme imzalanması gerekmektedir.

Metropolitan Sanat Müzesi galerilerinde gerçekleştirilen kopyalama çalışmalarıyla ilgilenen sanatçılar, sonbahar dönemi (Ekim-Aralık) veya bahar dönemi (Şubat-Mart) boyunca ücretsiz sekiz haftalık bir oturuma katılmak için başvurabilmektedirler. Müze başvuruları, yalnızca çevrimiçi başvurular şeklinde kabul etmekle birlikte başvuru koşulları "kopyalama program hükümleri" ve "sanat eseri kopyalama talep formunda" yer almaktadır. Kopyalama programı yalnızca profesyonellere değil aynı zamanda üniversite, kolej ve farklı atölye gruplarına da durum bazında ve müsait olma durumuna bağlı olarak açıktır. Müzede ayrıca ziyaretçilerin de eskiz ve kopyalama yapmalarına izin verilmekte ancak ziyaretçilerin müzenin belirlemiş olduğu eskiz ve kopyalama kurallarına uymaları gerekmektedir. Müze ziyaretçileri ise istedikleri zaman yalnızca kurşun kalem kullanarak izin almaksızın galerilerde çizim yapabilmektedirler (Metropolitan Museum, 2019b).

Metropolitan Sanat Müzesinin kopyalama programı kapsamında belirlediği koşullar şöyledir; Program dönemi boyunca bir sanatçı yalnızca bir sanat eserini kopyalanabilir. Tüm kopyalama istekleri küratörlük ve güvenlik onayına tabidir ve yalnızca Metropolitan Sanat Müzesi koleksiyonundaki çalışmalar kopyalanabilir. Ödünç verme sistemiyle müzeye getirilmiş eserler kopyalanamaz. Galerideki veya web sitesinde bulunan koleksiyon alanındaki eserin koleksiyonda olduğunu gösteren ve Metropolitan Müzesi giriş numarasını içeren sanat eserini tanımlayan etiketler dikkate alınır ve yalnızca kopyalama izninde belirtilen sanat eserleri kopyalanabilir. İzin belgeleri her zaman sanatçının yanında olmalı ve kopyanın müzeden çıkarılmadan önce, kopyalama ofisine sunulması gerekmektedir. 
Müze, kopyalama izni verilen çalışmalara kesintisiz erişim garantisi vermemektedir. Galeriler önceden bildirilmeksizin kapatılabilmekte ve bu tür durumlarda müze kopyalama çalışması yapan sanatçıyı önceden bilgilendirmek için her türlü çabayı göstermektedir. Eğer bir galeri beklenmedik bir şekilde kapatıldıysa, kopya çalışmanın tamamlanması için bir gün planlanmakta ve sanatçıya bildirilmektedir. Katılımcılar belirlenen bu günlerin dişında ayrıca bir zaman talep edemezler. Bir personel tarafindan eşlik edilmedikçe, müzenin halka açık olmayan bölgelerinde kopyalama çalışmalarına izin verilmez. Kopyalamaya devam edilen veya tamamlanan işler müzede satılamaz. Galerilerde kopyalama programına katılan sanatçıların, çalışanların ve ziyaretçilerin kopyaladıkları sanat eserine erişmesine izin vermesi beklenir. Tuvaller 30 inç $(76,2 \mathrm{~cm})$ geçmemeli ve orijinal sanat eserinin boyutlarından en az yüzde 10 farklı olmalıdır. Kil heykelleri bir kübik ayağ 1 geçmemelidir ve sadece yağ bazlı kil kullanım için onaylanmıştır. Devam eden çalışmalar müzede saklanır ve kopya tamamlanana veya izin süresi doluncaya kadar müzeden çıkartılamaz. Tamamlanan kopya çalışmayı müzeden çıkarmak için yetkili bir personel tarafından onaylanmış bir paket gerekmekte ve paket geçişleri en az 24 saat önceden bildirilmesi gerekmektedir. Kopyacılar çalışma alanlarında zemini korumak için temizlik bezleri kullanmalıdır. Şövale, tüm sanat eserlerinden en az dört metre uzakta yerleștirilmelidir. Güvenlik görevlileri, küratörler ya da eğitim görevlileri, kopyalama yapan sanatçıların uygun şekilde konumlandırılması konusunda yönlendirici olabilir ve müdahale edebilirler. Şövale, diğer herhangi bir teçhizat veya malzeme galerilerde asla gözetimsiz bırakılmamalıdır. Tüm firça temizliği evde yapılmalıdır. Kopyalama çalışması yapan sanatçılar tarafından, şövale ve ekipman temizlenerek geri gönderilmelidir. Yanıcı oldukları için müzede hiçbir boyama malzemesi depolanamaz. Programa katılan sanatçıların bu kurallara ve düzenlemelere uymaması ya da başka şekilde uygunsuz davranış sergilemesi durumunda, müze verilen izni askıya alabilir veya iptal edebilir (Metropolitan Museum, 2019c).

Metropolitan Sanat Müzesinin kopyalama programı kapsamında belirlediği yönerge ise şu şekilde hazırlanmıştır. Programa katılacak sanatçıların, önceden seçtiği sanat eserinin yerini ve konumunu görmek için müzeyi ziyaret etmesi önerilmektedir. Çoğunlukla, seçilen orijinal resmi içeren galerinin çok küçük olması durumunda veya çalışma alanının ziyaretçilerin görüş açılarını potansiyel olarak engelleyebileceği durumlarda kopyalama isteği reddedilmektedir. Programa katılacak sanatçılar, müzenin koleksiyonunun herhangi bir bölgesinde çalışmayı önerebilirken; boyut kısıtlamaları ve ziyaretçi trafik akışı nedeniyle, bazı galerilerdeki eserlerin kopyalanmasına izin verilmemektedir. Cézanne, Monet veya Van Gogh'un eserleri hiçbir galeride kopyalanamaz ayrica El Greco'nun "View of Toledo" isimli eseri de kopyalanamayan eserler arasındadır. Ayrıca geçici sergilerdeki çalışmaların da kopyalanması mümkün değildir. Kullanılabilecek malzemeler; resim çalışmaları için, yağlı boya (çözücü kısıtlamaları ile), akrilik ve guaj boya, heykel çalışmalar için; yağlı kil, tekstil için ise; elde dikiş nakışı olanaklı kılan araç gereçler olarak belirlenmiştir. Galerilerde başka materyallerin kullanılmasına ilişkin taleplerin de dikkate alınacağ 1 belirtirken, sanatçıların istekte bulunurken öncelikle, orijinal sanat eserlerinin güvenliğini göz önünde bulundurmaları gerektiği vurgulanmaktadır (Metropolitan Museum, 2019d).

Müze ziyaretçileri ise, müzenin her yerine kurşun kalem ile çizim yapmakta serbesttir ve bu nedenle ziyaretçilerin galerilerde çizim yapma istekleri kabul edilmektedir. Metropolitan Sanat Müzesi, bu kapsamda bir de "eskiz politikası" belirlemiştir. Müzenin belirlediği eskiz yönergesine göre; müzenin tüm kalıcı koleksiyon galerilerinde ve güncel sergilerin olduğu galerilerde sadece kurşun kalemle çizim yapılmasına izin verilmektedir. Müzede eskiz yapan müze ziyaretçilerine tükenmez kalem, mürekkep, kalem, dolma kalem veya sulu boya kullanımına hiçbir zaman izin verilmemektedir. Sadece pastel boya, kuru pastel ve odun kömürü kullanımlarını özellikle onaylayan müze, denetimli turlarda bu malzemelerin kullanılmasını kabul edebilmektedir. Eskiz yapan kişilerin galerilerdeki ziyaretçi akışını engellememeleri gerekmektedir. Metropolitan Sanat Müzesi, yoğun katılımın olduğu yani müzenin kalabalık olduğu dönemlerde, eskiz politikasında gerekli düzenlemeleri yapma hakkını saklı tutmaktadır. Metropolitan Sanat Müzesi, gelen profesyonel sanatçı ya da ziyaretçilerin eskiz taleplerini, atölye programı birimlerinde değerlendirmekte ve karşılaşılan herhangi bir sorun durumunda da katılımcıları bu birime yönlendirmektedir (Metropolitan Museum, 2019d). 


\section{Ulusal Sanat Galerisi (National Gallery of Art)}

Ulusal Sanat Galerisi, 1937 y1lında Washington'da kurulan ve 1941 yılında halka açılan, koleksiyonu öncelikle Rönesans'tan günümüze Avrupa ve Amerikan sanatını temsil eden eserlerden oluşan bir sanat müzesidir. Amerika Birleşik Devletleri'nin Washington DC kentinde bulunan Ulusal Sanat Galerisi, koleksiyonunu, binalarını ve programlarını tüm izleyiciler için erişilebilir kılmayı taahhüt etmektedir. Ulusal Sanat Galerisinin sosyal hizmet anlayışı doğrultusunda gerçekleştirdiği kopyalama programı, müzenin halka açıldığı tarihten bu yana sağladığı hizmetlerin önemli bir parçası olmuştur (Resim 13) (National Gallery of Art, 2019).

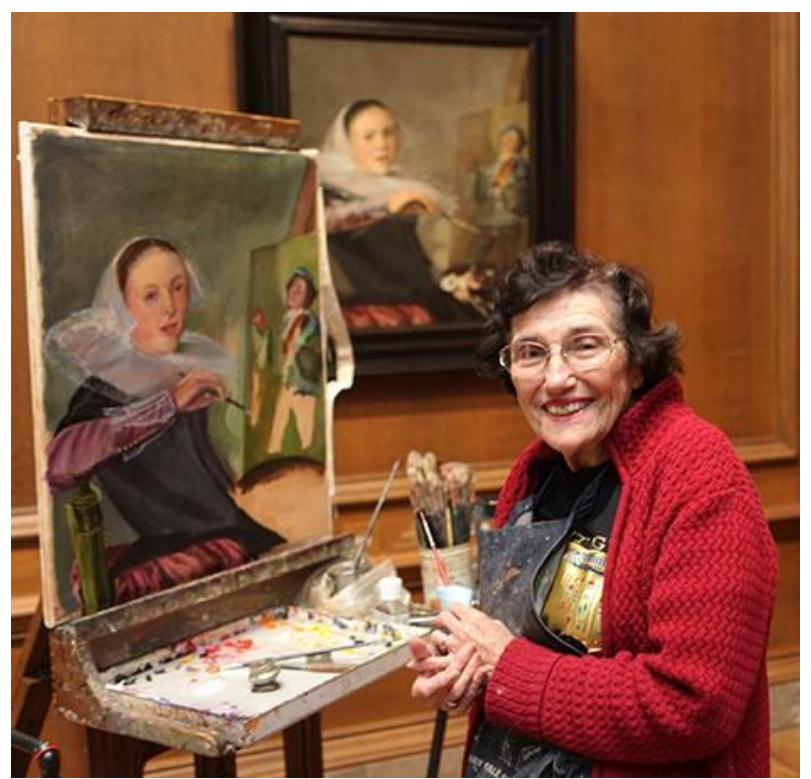

Resim: 13 "Ulusal Sanat Galerisi'nde resim kopyalayan bir sanatçı”.

[(https://www.nga.gov/visit/copyist.html), (Ert.15.05.2019)].

Ulusal Sanat Galerisi'ndeki kopyalama programı, sanatçılara eski ustaların tekniklerini galerilerde gerçekleştirebilecekleri derin çalışmalarla incelemeleri için eşsiz bir firsat sunmaktadır. 1941'de müze halka açılmadan önce, müzedeki eserlerin müze duvarları dışında da kullanılabilmesine ve sanatçıların müzenin başyapıtlarını kopyalayabilmelerine yardımcı olacak bir programın kurulmasına mütevelli heyeti tarafından karar verilmiş̧ir. Programın başlangıcından bu yana Galeri'deki resimlerin kopyalanması için sekiz binden fazla izin verilmiştir. Ulusal Sanat Galerisi kopyalama programına katılmak isteyen sanatçılar belirtilen boya, firça, bez gibi tüm gereksinimleri kendileri karşılamak durumundadır. Sanatçıların bu programa katılabilmesi için Ulusal Sanat Galerisi'nin belirlemiş olduğu yönergeye uymak durumundadır. Müzenin belirlemiş olduğu "sanat yapıtlarını kopyalama yönetim kurallarına" e-posta yoluyla ulaşılabilir ve e-posta yoluyla başvuru yapılabilir. Başvuruları ön değerlendirmeden geçen adaylar, mülakat için çağırılırlar ve kabul edilen sanatçılar bu kuralları kabul ettiklerini yazılı olarak da bildirmek zorundadır (National Gallery of Art, 2019).

Sanat eserlerinin yağ veya başka bir sıvı çözücülerle kopyalanması için kayıt memuru tarafından verilen izinlerin gerekli olduğunu sanatçı tarafından dikkate alınmalıdır. Ulusal Sanat Galerisi, programa katılacak sanatçıların, şövale ve tabure kullanımına, boya dökülmelerine karşı altına bez serilmesi şartıyla izin vermekte ve bu gereçler müze tarafindan sağlanmakta ancak sanatçıların özel şövale getirmelerine izin verilmemektedir (National Gallery of Art, 2019).

Müze ziyaretçileri ise galerilerde kalemleri ve diğer kuru materyalleri kullanarak istedikleri zaman çizim yapabilmektedirler (Resim 14). Ulusal Sanat Galerisi'nin belirlemiş olduğu bir de eskiz politikası vardır. Belli kurallar içeren ve ziyaretçilerin eskiz çizebilmelerine yardımcı olacak ipuçlarını içeren bu yönergeye müzenin web sayfasından da ulaşılabilmektedir (National Gallery of Art, 2019). 


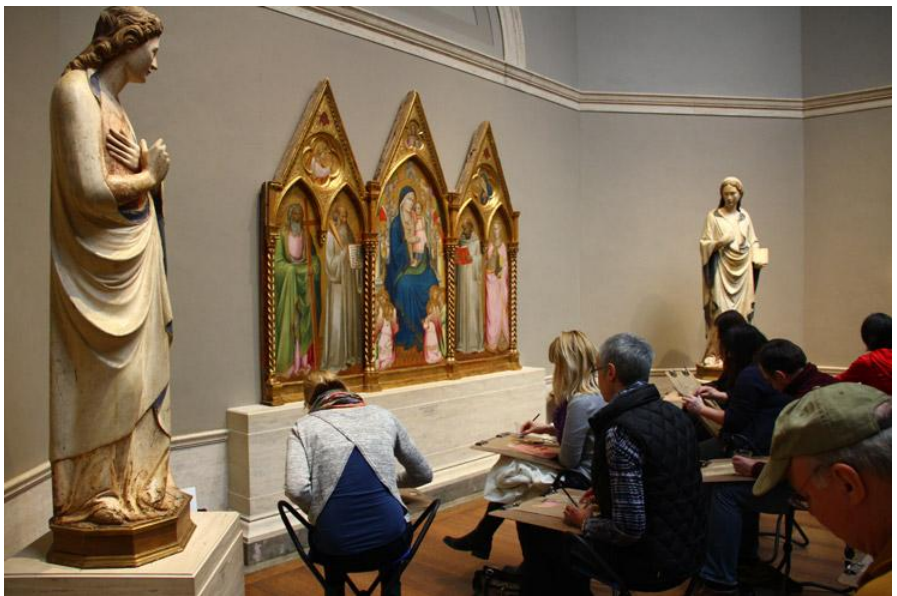

Resim: 14 "Ulusal Sanat Galerisi’nde eskiz yapan ziyaretçiler”.

[(https://www.nga.gov/education/adults/drawing-salon.html), (Ert.15.05.2019)].

\section{Walters Sanat Müzesi (Walters Art Museum)}

Walters Sanat Müzesi, Amerika Birleşik Devletleri'nin Baltimore kentinde 1934 yılında kurulmuş bir sanat müzesidir. Walters Sanat Müzesi'nin koleksiyonları, sanatçıların ve sanat öğrencilerinin çalışmalarına ilham verecek ve bundan keyif alabilmelerini sağlayacak biçimde kullanıma açılmıştır (Walters Art Museum, 2019).

Walters Sanat Müzesi, mevcut ve gelecekteki ziyaretçileri için koleksiyonlarını korumak için çabalarken galerilerinde de resim yapmayı teşvik etmektedir. Müze ziyaretçilerinin görüş açısını ve ziyaretçi akışı engellenmediği sürece kalıcı koleksiyonlardan resim kopyalanmasına ve eskiz çizimlerine izin verilmektedir. Müzenin daimî koleksiyonunda yer almayan, ödünç alınan sanat eserlerinin sahipleri ile yapılan sözleşme yükümlülükleri ve güvenlik önlemleri gereğince kopyalama izinleri kısıtlanabilmektedir. Kopyalama çalışmaları, güvenlik bölümünün takdirine bağlı olarak, müzedeki ziyaretçi akışının çok yoğun olduğu zaman dilimlerinde kısıtlanabilir. Walters Sanat Müzesi çalışanları, listelenmemiş tüm ekipman ve malzemeleri önceden onaylamak zorundadır. Müzede eskiz çalışmaları, küçük veya orta büyüklükteki altlıklar, kurşun kalem, kömür ve pastel gibi kuru malzemeler kullanılmak koşuluyla önceden güvenlik takdirine bağlı onay alınmadan yapılabilmektedir. Müzede resim yapmak isteyen sanatçıların ise galerideki kopyalama politikalarına erişebilmesi ve belirtilen koşulları kabul ettiğini bildirmesi için önceden müzeyle irtibata geçmeleri gerekmektedir. Kopyalama koşullarını kabul ettiklerini bildiren kabul formu, müzeyi ziyaret etmeden en az iki hafta önce doldurulmalı, imzalanmalı ve müzeye teslim edilmelidir. Kopyalama programına kabul edilen sanatçılar kullanacakları resim malzemeleri ile müzeye girdikten sonra, danışma masasında fotoğraflı kimlik belgesi ibraz etmesi ve getirdiği malzemeleri güvenlik görevlisinin kontrol etmesi için teslim etmesi gerekmektedir. Sanatçı müzede kopyalama çalışmasına başlamadan önce konumunu, ziyaretçilerin görüş açısını kısıtlamayacak ve müzedeki ziyaretçi trafiğini engellemeyecek şekilde belirlemesi gerekmektedir. Kopyalama yapan sanatçının konumundan dolayı, ziyaretçilerin veya sanat eserlerinin güvenliği konusunda endişe duyulması durumunda, sanatçıdan şövalesinin konumunu değiştirmesi istenebilir. Sanatçılar, orijinal sanat eserinden en az üç metre uzakta durmalı ve hiçbir nesneye veya resme dokunmamalıdır. Kullandıkları şövale ise tüm sanat eserlerinden en az dört metre uzakta olmalıdır. Sanatçı eğer resim yapıyorsa, çalışma alanındaki zemini korumak için yere yeterince geniş bir bez sermelidir. Sanatçı tüm malzemelerini yerleştirdikten sonra şövalesinin ve diğer ekipmanlarının yerini izinsiz bir şekilde değiştiremez. Çalışma sırasında ya da sonrasında kullanılan çözücü sıvılar, boyalar ve firçalar dahil olmak üzere hiçbir malzeme gözetimsiz bırakılmamalıdır. Ziyaretçileri, sanat eserlerini ve binayı, kaza, yaralanma veya hasardan korumak için tüm malzemeler güvenli bir şekilde kullanılması gerekir. Kullanılacak tiner terebentin gibi tüm sıv1 malzemeler kapaklı kaplarda bulunmalı kullanımı için, küçük bir erişim deliği olan kapaklar sağlanmalı ve diğer ziyaretçiler tarafından erişilebilir olmamalıdır. Galerilerde açık kaplarda su veya kimyasal madde taşınması, sprey, fiksatif ve vernik kullanılması da yasaktır (Walters Art Museum, 2019). 
Walters Sanat Müzesi, kopyalama çalışmalarının en iyi şekilde yürütülebilmesi ve yaşanabilecek sorunların önüne geçmek adına etik meselesini de göz önünde buldurarak bazı özel kısıtlamalar getirmiştir. Orijinal sanat eserlerini kopyalamalarken ölçü kısıtlamaları getirilmiştir. Herhangi bir kopya çalışmanın ölçüsü, orijinal sanat eserinden en az 2 inç $(5,08 \mathrm{~cm})$ yükseklikte ve eninde farklı olmalıdır ve bu kuralın istisnası yoktur. Hiçbir kopya çalışmanın boyutu, orijinal eserin boyutuna bakılmaksızın her iki boyutta 36 inç'i $(91,44 \mathrm{~cm})$ aşamaz. Orijinal eserdeki sanatçının imzası kopyalanırsa, imzanın yanına "den sonra kopyalayan" ibaresi yazılmalı ardından kopyacının adı ve tarihi eklenmelidir. Kullanacak malzemelere de belli kısıtlamalar getirilmiştir. Bu malzemelerin mutlaka görevliler tarafindan kontrol edilmesi ve onaylanması gerekmektedir. Genellikle, kalemler, kömür, suluboya ve pastel akrilik, yağlı boya, terebentin, keten tohumu yağı ve toksik olmayan boya tinerleri gibi malzemelerin kullanılması onaylanmaktadır. Müzede uygulanan başka bir kısıtlama da galerilerde kopyalama yapacak sanatçıların sayısı ile ilgilidir. Orijinal sanat eserinin ve ziyaretçilerin güvenliği için, bir galeride çalışmasına izin verilen sanatçı sayısı sınırlıdır ve bu sayının belirlenmesi müze personelinin takdirindedir. Bir sanatçının resim yaptığı galeride bir tur ya da konuşma yapılırken, sanatçının çalışma yaptığı alandan uzaklaşması istenebilir. Müzede bir de ekipman kısıtlamaları uygulanmaktadır. Sanatçılar, ihtiyaç duydukları malzemeleri kendilerinin sağlaması gerekmektedir. Kullanılacak şövalenin çok sağlam ve galeri tabanına zarar vermeyecek nitelikte olması ve mutlaka müze görevlileri tarafindan onaylanması gerekmektedir. Sanatçılar yine kullanacakları sıvı kaplarını, temizlik bezlerini ve zemine serecekleri koruma bezlerini kendileri temin etmek durumundadırlar. Şövale müze tarafından sanatçılara sağlanmaktadır ancak kendi şövalelerini kullanmak isteyen sanatçıların öncede müze güvenliğinden onay almaları gerekmektedir. Sanatçılar, kullandıkları kimyasal atıkları müze dışında imha etmek zorundadır. Kullanılan kimyasalların kesinlikle müzenin evyelerinde imha edilmesine izin verilmez. Fırçalar ve ekipmanlar da müze tesislerinde temizlenemez. Walters Sanat Müzesi, herhangi bir nedenle, galerilerde eskiz veya kopyalama iznini iptal etme hakkını saklı tutar (Walters Art Museum, 2019).

\section{SONUC}

Kopyalama geleneği, ilk kez 1793 yılında Fransa'da Louvre Müzesi’nde başlamış ve Avrupa'daki prestijli sanat müzelerinde hızla yayılmış olsa da Amerika'daki sanat müzelerinde bu uygulamaların, Avrupa'dan yaklaşık 80 yıl sonra 1872 yılında başladığı görülmektedir. Öte yandan, Amerika'daki müzeler kopyalama çalışmalarına, Avrupa'daki müzelerden çok daha geç başlamış olmalarına rağmen, çağdaş müzeciliğin gerektirdiği eğitim misyonunu öne çıkaran sanatçı ve ziyaretçi odaklı kopyalama programlarıyla günümüzde bayrağı en önde taşıdıkları ortadadır. Günümüzde önemli sanat müzelerinin çoğunda kopyalama programlarına yer verilmesi beklenirken, çok emek gerektiren bu programlar için gerekli mali kaynağın ve uygun fiziksel ortamın sağlanamaması ya da kopyalama geleneğinin eski moda bir akım olarak görülmesi gibi anlayış farklılıkları nedeniyle her müzede bu programlara yer verilemediği görülmektedir. Ancak sanatçılara ve sanat öğrencilerine, dünyaca kabul görmüş değerli sanatçıların eserlerinden kopyalama yaparak teknik deneyim kazanmalarına olanak sağlayan ve müze ziyaretçilerinin de oldukça ilgi gösterdiği bu programların toplumsal işlevlerini göz ard1 etmemek gerekir.

Sanat müzelerindeki kopyalama programlarını tarihsel bağlamında değerlendirirken, Avrupa ve Amerika müzelerindeki uygulama anlayışlarının birbirlerinden keskin çizgilerle ayrıldığ 1 görülse de Amerika'daki sanat müzelerinde bir iç tutarlılığın olduğu ve kopyalama programlarının ortak bir anlayışta tasarlandığı ve yürütüldüğü görülmektedir. Örneğin; İspanya'nın en önemli sanat müzelerinden biri olan ve kopyalama geleneğini 1860'dan günümüze taşıyan Prado Müzesi'nde kopyalama programlarına katılan sanatçılardan belli bir ücret talep edilirken, Amerika'daki sanat müzelerinde; Metropolitan Sanat Müzesi örneğinde olduğu gibi kopyalama programlarına katılan sanatçılardan herhangi bir ücret talep edilmediği hatta belli dönemlerde sanatçıların burslarla desteklendiği bilinmektedir. Dünyada bu programları uygulayan sayısız müze arasından en kapsamlı şekilde uygulayan sanat müzelerinden olan; Metropolitan Sanat Müzesi, Ulusal Sanat Galerisi ve Walters Sanat Müzesi’ndeki kopyalama programlarının genel bir değerlendirmesi yapıldığında, uygulama anlayışlarının ülkeden ülkeye hatta aynı ülkede olsalar dahi müzeden müzeye değiştiği 
ancak bazı temel değişmez prensiplerin olduğu görülmektedir. En fazla öne çıkan bu genel prensiplerin başında etik konusu dikkati çekmektedir. Kopyalama programları olan müzelerin hiçbirinde sahteciliği önlemek adına orijinal bir eserin birebir ölçülerinde kopyalanmasına ya da sanatçının orijinal imzasını atıf yapmadan kopyalanmasına asla izin verilmemektedir. Bu programları uygulayan sanat müzelerinin tamamı kopyalama çalışmaları süresinde meydana gelebilecek tehlikelere karşı, orijinal sanat eserin güvenliğini ön planda tutmakta, bu doğrultuda sanatçıların uyması gereken belirli kurallar ortaya koymaktadır. Ayrıca bu sanat müzelerinde, kopyalama çalışmalarının, müzenin ziyaretçi akışını bozmaması ve ziyaretçilerin görüş açısını engellememesi adına önlemler alınmakta ve müze ziyaretçilerinin hakları gözetilmektedir.

Günümüzde dünyanın önde gelen sanat müzelerinde kopyalama programlarının etkin bir biçimde uygulandığı, sanatçılar ve halk tarafindan kabul gördüğü açıktır. Sanat müzelerinin, sanatçılara sunduğu kopyalama programları, yalnızca sanatçıların deneyimlerine katkı sağlamakla kalmaz, müze görevlilerinin ve müze ziyaretçilerinin deneyimlerini de zenginleştirir. Müze ziyaretçilerinin, müzenin duvarında asılı duran orijinal bir sanat eseri üzerinde çalışan bir sanatçıyı görmeleri, onların sanat galerisini ziyaret etme deneyimlerine çok şey katacağı açıktır. Öte yandan, gelişmiş ülkelerin sanat müzelerinde uzun yıllardır sürdürülen kopyalama programlarının, Türkiye'deki sanat müzelerinde varlığından söz etmek mümkün değildir. Bu bağlamda, Türkiye'deki sanat müzelerinde de kopyalama programları ile sanatçılara ve sanat öğrencilerine, ustaların eserlerine erişim olanağı sağlanarak teknik deneyim kazanmaları için destek verilebilir. Dolayısıyla Türkiye'nin çağdaş müzecilik yolundaki hedeflerinden biri de sanatçıları her bağlamda destekleyecek kopyalama programlarını, sanat müzeleri genelinde yaygınlaştırmak, bu programların sürdürülebilirliği sağlayacak uzman personeli yetiştirmek ve uygulanabilir bir kopyalama politikası oluşturmak olmalıdır.

\section{KAYNAKÇA}

Blakemore, E. (2016). What's with the people with easels in art museums? [Blog yazis1]. 2 Haziran 2019 tarihinde https://www.smithsonianmag.com/smart-news/whats-people-easels-artmuseums-180960261/ adresinden erişildi.

Brooklyn Museum, (2019). Art-students and copyists in the Louvre Gallery, Paris. 2 Haziran 2019 tarihinde https://www.brooklynmuseum.org/opencollection/objects/2482 adresinden erişildi.

Clark Museum, (2019). Americans abroad-The copyist in the Louvre. 2 Haziran 2019 tarihinde https://www.clarkart.edu/Collection/6382 adresinden erişildi.

Graves, J. (2008, 21 Ağustos). No, not here, that's not possible / Why can't artists be artists at sam and the frye? The Stranger. 2 Haziran 2019 tarihinde https://www.thestranger.com/issues/648112/2008-08-21 adresinden erişildi.

Gutiérrez, M. C. B. (2017). Los copistas del Museo del Prado. La revalorización de la copia de maestros en el aprendizaje del artista.: La importancia de la copia. Unpublished doktoral thesis. Universidad Autónoma de Madrid, İspanya.

Jacobs, E. (2019, 06 Mart). Why 19th-century Paris had a museum full of copies [Blog yazıs1]. 2 Haziran 2019 tarihinde https://www.atlasobscura.com/articles/paris-museum-of-copies adresinden erişildi.

Türk Dil Kurumu. (2005). Türkçe sözlük. Ankara: TDK Yayınları.

Türk Dil Kurumu. (1968). Türk dil kurumu güzel sanatlar terimleri sözlüğ̈̈. Ankara: TDK Yayınları

Lesser, C. (2018). How artists are copying masterpieces at world-renowned museums [Blog yazıs1]. 2 Haziran 2019 tarihinde https://www.artsy.net/article/artsy-editorial-artists-allowed-copymasterpieces-worlds-prestigious-museums adresinden erişildi.

Metropolitan Museum, (2019a). About the met. 2 Haziran 2019 tarihinde https://www.metmuseum.org/about-the-met adresinden erişildi. 
Metropolitan Museum, (2019b). Copyist program. 2 Haziran 2019 tarihinde https://www.metmuseum.org/events/programs/met-creates/copyist-program adresinden erişildi.

Metropolitan Museum, (2019c). The met copyist program: Terms and conditions. 2 Haziran 2019 tarihinde https://www.metmuseum.org/media/files/events/programs/copyistprogram termsconditions. pdf adresinden erişildi.

Metropolitan Museum, (2019d). The met copyist program: Guidelines for requesting to copy a work of art. 2 Haziran 2019 tarihinde https://www.metmuseum.org//media/files/events/programs/copyist-guidelines.pdf adresinden erişildi.

Museu Nacional d'Art de Catalunya, (2019). Copista en el Museu del Louvre (Copyist in the Louvre Museum). 2 Haziran 2019 tarihinde https://www.museunacional.cat/en/colleccio/copista-enel-museu-del-louvre-copyist-louvre-museum/isidre-nonell/041090-d adresinden erişildi.

Newsom, B. Y., \& Silver, A. Z. (1978). The art museum as educator: A collection of studies as guides to practice and policy. Berkeley, CA: University of California Press.

Quito, A. (2016). Fine reproductions. [Blog yazıs1]. 2 Haziran 2019 tarihinde https://qz.com/795521/the-rijksmuseum-dutch-national-art-museum-is-actually-rewardingartists-and-designers-who-copy-its-masterpieces/ adresinden erişildi.

Smithsonian American Art Museum, (2019). Copyist at the Metropolitan Museum (An amateur artist). 2 Haziran 2019 tarihinde https://americanart.si.edu/artwork/copyist-metropolitan-museumamateur-artist-22490 adresinden erişildi.

Sözen, M. ve Tanyeli, U. (2009). Sanat kavramlart ve terimleri sözlüğü, İstanbul: Remzi Kitapevi.

Whitney Museum of American Art, (2019). The copyist 1930. 2 Haziran 2019 tarihinde https://whitney.org/collection/works/10228 adresinden erişildi.

Valladares, M. (2016). Art, Features, Interviews, New Yorker Spotlight, People/ Spotlight: Maya Valladares helps artists copy famous works at The Metropolitan Museum of Art. 2 Haziran 2019 tarihinde https://www.6sqft.com/spotlight-maya-valladares-helps-artists-copy-famousworks-at-the-met-museum/ adresinden erişildi. 